\title{
HISTORICKÝ VÝVOJ A AKTUÁLNÍ SITUACE NA POLSKÉM AKCIOVÉM TRHU
}

\author{
Lukáš Chylík
}

\section{Klíčová slova:}

Kapitálové trhy, Varšavská burza, analýza akciového trhu, burzovní index, historický vývoj

\section{Key words:}

Capital markets, Warsaw Stock Exchange, stock markets analysis, stock index, historical development

\begin{abstract}
Abstrakt
Článek se zabývá základní charakteristikou kapitálového trhu v Polsku, se zaměřením na akciový trh. Na úvod je popsán historický vývoj daného trhu a následně je provedena analýza historického vývoje nejdůležitějších ukazatelů, jako jsou vývoj hlavního burzovního indexu WIG20, tržní kapitalizace, počet obchodovaných společností na burze apod. Základním srovnávacím ukazatelem pro lepší vypovídací schopnost byla zvolena Burza cenných papírů v Praze, včetně hlavního indexu PX.
\end{abstract}

\begin{abstract}
The article deals with the basic characteristics of the capital market in Poland, focusing on the stock market. The introduction describes the historical development of the market and subsequently analyzed the historical development of key indicators such as the development of the main stock market index WIG20, market capitalization of companies traded on the stock exchange, etc. The main comparative indicator for the better explanatory power was selected Stock Exchange in Prague including the main index PX.
\end{abstract}

\section{Úvod}

Kapitálový trh v Polsku zažívá v posledních letech největší rozmach se zemí Visegrádské čtyřky a nechává je daleko za sebou při svém rozmachu a rozvoji. Žádná z okolních zemí a ani žádná se zemí bývalého sovětského svazu, nezažívá takový rozmach kapitálového trhu, jako nyní prožívá polský kapitálový trh.

Cílem článku je zanalyzovat kapitálový trh v Polsku, představit jeho základní strukturu a především se zaměřit na představení akciového trhu v Polsku a zachytit historický vývoj nejdůležitějších ukazatelů, jako jsou vývoj hlavního burzovního indexu WIG20, tržní kapitalizace, počtu obchodovaných společností na burze apod. Veškeré tyto ukazatele podávají obrázek o tom, jak výkonný je v současné době akciový trh v Polsku. Základním srovnávacím ukazatelem pro lepší vypovídací schopnost byla zvolena Burza cenných papírů Praha, včetně hlavního indexu PX.

\section{Struktura kapitálového trhu v Polsku}

Základní strukturu polského kapitálového trhu nám znázorňuje grafické schéma č. 1.1 . uvedené níže. 
Graf 1.1 Struktura polského kapitálového trhu

I Structure of The Polish Capital Market

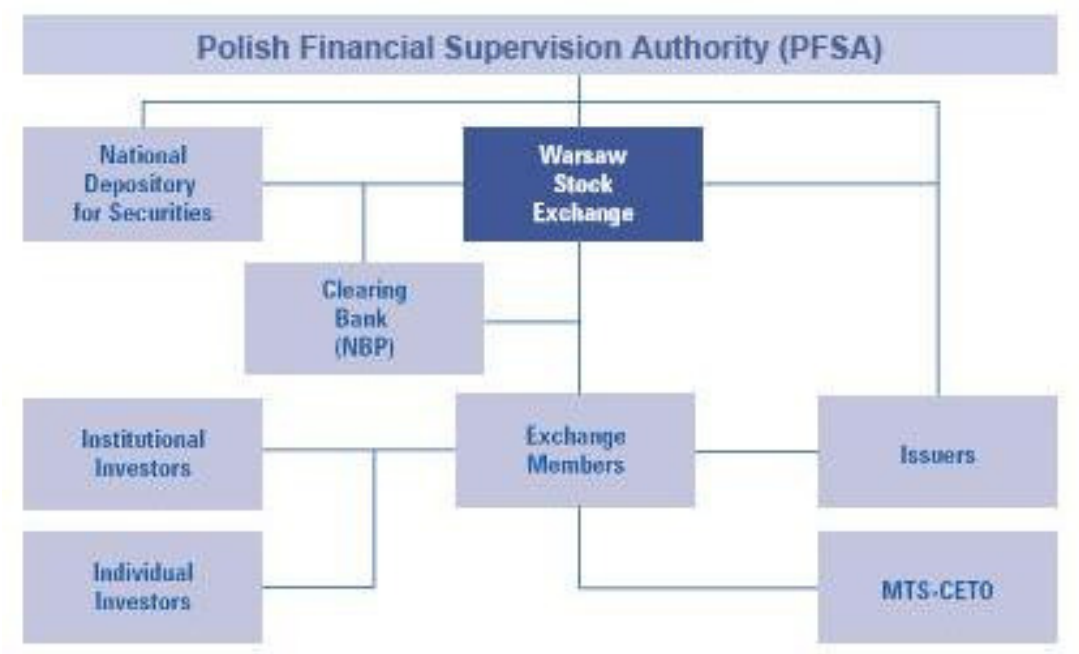

Zdroj: http://www.gpw.pl/

Nejdůležitějším regulačním orgánem na polském kapitálovém trhu je orgán PFSA („Orgán polského finančního dohledu“), který zajišt'uje dohled nad bankovnictvím, kapitálovými trhy, pojištěním a důchodovém systému. PFSA byl založen 19. záŕí 2006 a od té doby prošel podobným vývojem jako ČNB v České republice, kde na něj přešli veškeré kontrolní kompetence nad oblastí pojišt'ovnictví, penzijního připojištění a v neposlední řadě taktéž nad oblastí finančního trhu v Polsku, kde převzal kompetence od zaniknuvší Komise pro cenné papíry. Uvedený proces sloučení regulačních kompetencí byl ukončen 1. ledna 2008.

Základním stavebním článkem polského kapitálového trhu je Burza cenných papírů ve Varšavě. Vypořádání obchodů probíhá prostřednictvím „Národního depozitáře cenných papírů (NDS)“, které také zajišt'uje peněžní vypořádání obchodů. Dalším důležitým subjektem je Zúčtovací banka (NBP), která především vykonává úlohu centrální banky. V neposlední řadě jsou součástí polského kapitálového trhu jednotlivý členové burzy (viz. Př́loha 1), emitenti a taktéž samotní investoři. Jelikož nejdůležitější roli hraje Burza cenných papírů ve Varšavě, bude výzkum zaměřen především na daný subjekt.

\section{Varšavská burza cenných papírů (WSE)}

\subsection{Historický vývoj}

První burza cenných papíru byla v Polsku otevřena v květnu roku 1817 ve Varšavě. Předmětem obchodu zde byly především směnky a dluhopisy, obchod s akciemi se začal více rozvíjet až $\mathrm{v}$ druhé polovině 19. století. V meziválečném období mělo Polsko sedm burzovních trhů - ve Varšavě a dále v Katowicích, Lvovu, Lodži, Krakově, Poznani a Vilnu. Prvořadé postavení si i nadále ponechala burza ve Varšavě, kde se uskutečňovalo téměř $90 \%$ všech obchodi̊. Vlivem politických změn nebyly ostatní kapitálové trhy po druhé světové válce znovu otevřeny. V roce 1938 bylo na Varšavské burze kótováno asi 130 cenných papírů. V okamžiku vypuknutí 2 . světové války došlo, podobně jako v případě pražské burzy, k přerušení obchodování. 
Po roce 1945 došlo k pokusu znovu oživit činnost Varšavské burzy, ale nastupující centrálně plánovaná ekonomika nenašla pro obchod s cennými papíry pochopení. Po roce 1989 začal v Polsku, podobně jako u nás, návrat k základům tržního hospodářství. 12. dubna 1991 vznikla státní akciová společnost Varšavská burza cenných papírů. První obchodování se uskutečnilo 16. dubna 1991, na burze bylo $\mathrm{v}$ té době kótováno 5 společností. V roce 1997 pak počet kotovaných společností přssáhl stovku. V roce 1998 se začalo na burze obchodovat s warranty i s prvním futures kontraktem na index WIG, v roce 2000 se prridaly firemní dluhopisy a od roku 2001 se na burze obchoduje také s futures kontrakty na jednotlivé akciové tituly. Opce na indexy se přidaly v roce 2003 a v roce 2005 pak přibyly také opce na jednotlivé akcie.

Od roku 2003 začaly na burze ve Varšavě své akcie kótovat také zahraniční společnosti. První byla rakouská banka Creditanstalt, od roku 2006 pak začaly přibývat také společnosti z ČR. Na varšavské burze je kótovaných několik českých společností, např. ČEZ nebo NWR.

\subsection{Právní úprava obchodování na WSE}

Varšavská burza byla založena jako nezisková akciová společnost. Její základní kapitál činí 42 milionů PLN, který je rozdělen na 60.000 akcií na jméno. Podíly WSE mohou nakupovat pouze banky, makléřské domy, státní pokladna, pojištovny a emitenti cenných papírů schválených pro veřejné obchodování, které jsou současně uvedeny na WSE.

Varšavská burza cenných papírů má tř̌i základní řídící orgány a to Valnou hromadu, Dozorčí radu a Správní radu. Nejvyšším rozhodovacím orgánem je Valná hromada. Každá část řídícího orgánu WSE má přesně vymezené kompetence své činnosti včetně kontrolní činnosti a dále přesně stanovený počet svých členů včetně jejich zvoleného období.

\section{Právní rámec fungování burzy tvoři následující legislativní normy:}

- Zákon o obchodních společnostech z roku 2000

- Zákon o veřejné nabídce z roku 2005

- Zákon o obchodování s finančními nástroji ze dne 29. července 2005

- Zákon o dohledu nad kapitálovým trhem ze dne 29. července 2005

- Zákon o veřejném obchodování s cennými papíry z roku 1997

- Stanovy Varšavské burzy cenných papíru

- Burzovní pravidla Varšavské burzy cenných papíru

- Pravidla Burzovního rozhodčího dvoru ${ }^{1}$

\subsection{Obchodní trhy}

Cenné papíry jsou na varšavské burze kótovány na hlavním a paralelním trhu. Tyto dva základní trhy byly rozšířeny v srpnu roku 2007 o třetí trh, a to tzv. NewConnect trh, jak nám znázorňuje uvedené schéma 2.1

\footnotetext{
${ }^{1}$ Zdroj: http://www.gpw.pl/gpw.asp?cel=e_ogieldzie\&k=7\&i=/regulacje/opis\&sky=1
} 


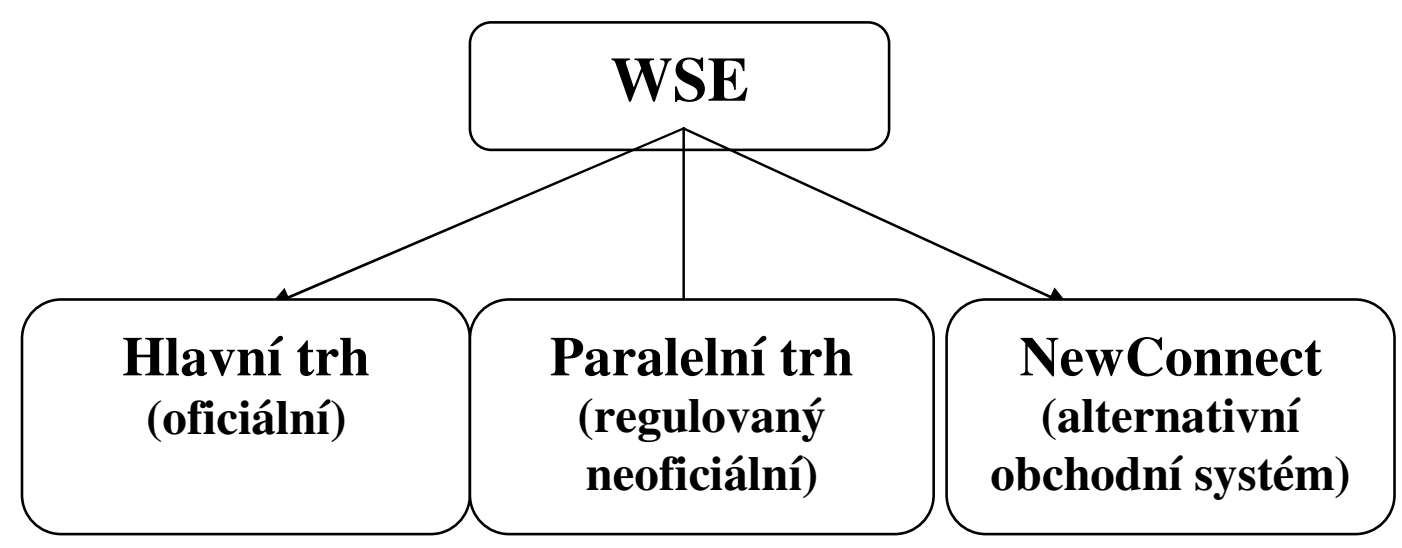

Zdroj: http://www.gpw.pl, vlastní zpracování

Jak nám uvedený graf napovídá, tak základním trhem varšavské burzy je hlavní trh, kde jsou obchodovány především nejlikvidnější a nejvíce obchodovatelné akcie na polské burze. Hlavní trh nese taktéž označení jako oficiální. Druhým trhem Varšavské burzy je paralelní trh, který nese označení regulovaný neoficiální trh. Na obou trzích je obchodováno jak s akciemi, které tvoří podstatnou část obchodů, tak i s ostatními cennými papíry a nástroji.

Nejnověǰ̌ím organizovaným trhem varšavské burzy je trh NewConnect ${ }^{2}$, který je provozován WSE mimo regulovaný trh jako alternativní obchodní systém, podobný trhu Alternative Investment Market (AIM) Londýnské burzy. NewConnect byl vyvinut pro mladé dynamické polské firmy s velkým růstovým potenciálem, které potřebují dostatečně vysoký vlastní kapitál, který mohou následně využít pro aplikaci vlastních inovací a následně dostat př́ležitost $\mathrm{k}$ růstu a stát se jednou $\mathrm{z}$ velkých firem $\mathrm{v}$ Polsku. $\mathrm{Z}$ těchto důvodů nabízí daný trh volnější povinnosti a požadavky, které jsou kladeny na úvodní emisi akcií, což v celkovém měřítku snižuje náklady a zatraktivňuje vstup na kapitálové trhy. Emitenti jsou přiváděni na NewConnect pomocí licencovaných poradců (Nomads), kteří odpovídají za emitenta po dobu 12-ti měsíců od uvedení na trh. Emitenti musí mít také svého market animátora (zjednodušené verze funkce „market makera“ známého např. z pražské burzy) po dobu 12- ti měsíců od uvedení na trh. Od zavedení trhu NewConnect na něj vstoupilo již 185 společností (mimo jiné v srpnu 2008 první zahraniční společnost - Photon Energy - developer fotovoltaických elektráren z ČR).

\subsection{Systém obchodování}

Prakticky od začátku se na burze obchoduje pouze elektronicky. Obchodování probíhá od 9:30 - 16:10. Standardní termín vypořádání obchodů je T+3. Od 17. listopadu $2000 \mathrm{k}$ tomu slouží systém WARSET (Warsaw Stock Exchange Trading systém), který je podobný systémům používaných při obchodování v Paříži, Bruselu, Amsterodamu nebo Chicagu. Obchoduje se zde v aukčním a kontinuálním režimu, ceny akcií jsou stanoveny na základě maximalizace objemu transakcí, prŕkazy jednotlivých účastníků jsou pak vyhodnoceny a nakonec spárovány.

\footnotetext{
${ }^{2}$ http://www.newconnect.pl
} 


\section{Burzovní index WIG20}

Nejstarším indexem varšavské burzy je WIG, který burza zavedla již v dubnu 1991 (výchozí hodnota byla stanovena na 1000 bodů). Jedná se o index výnosový, který zohledňuje výplatu dividend a předkupních práv. Do báze indexu jsou zahrnuty všechny emise obchodované na hlavním trhu varšavské burzy, kromě zahraničních společností a investičních fondů. Aktualizace báze probíhá vždy na konci čtvrtletí.

Hlavním indexem varšavské burzy v současnosti je WIG 20, který byl založen v roce 1994. Sleduje 20 největších a nejlikvidnějších akciových titulů na burze (tzv. „blue chips). Aktuální složení daného indexu nám znázorňuje tabulka 3.1. Podíl emisí jednoho odvětví nesmí být více než 5 společností. Aktualizace báze složení indexu probíhá v pravidelných ročních intervalech, ale menší úpravy jsou realizovány i ve čtvrtletních úpravách.

Varšavská burza publikuje celkově 18 indexů, například můžeme uvést několik sektorových indexů (např. WIGBanking, WIGDevelopers, WIGTelecom atd.) a také index zahrnující středně velké společnosti mWIG40 a pro malé společnosti sWIG80.

Graf 3.1. Historický vývoj burzovního indexu WIG20

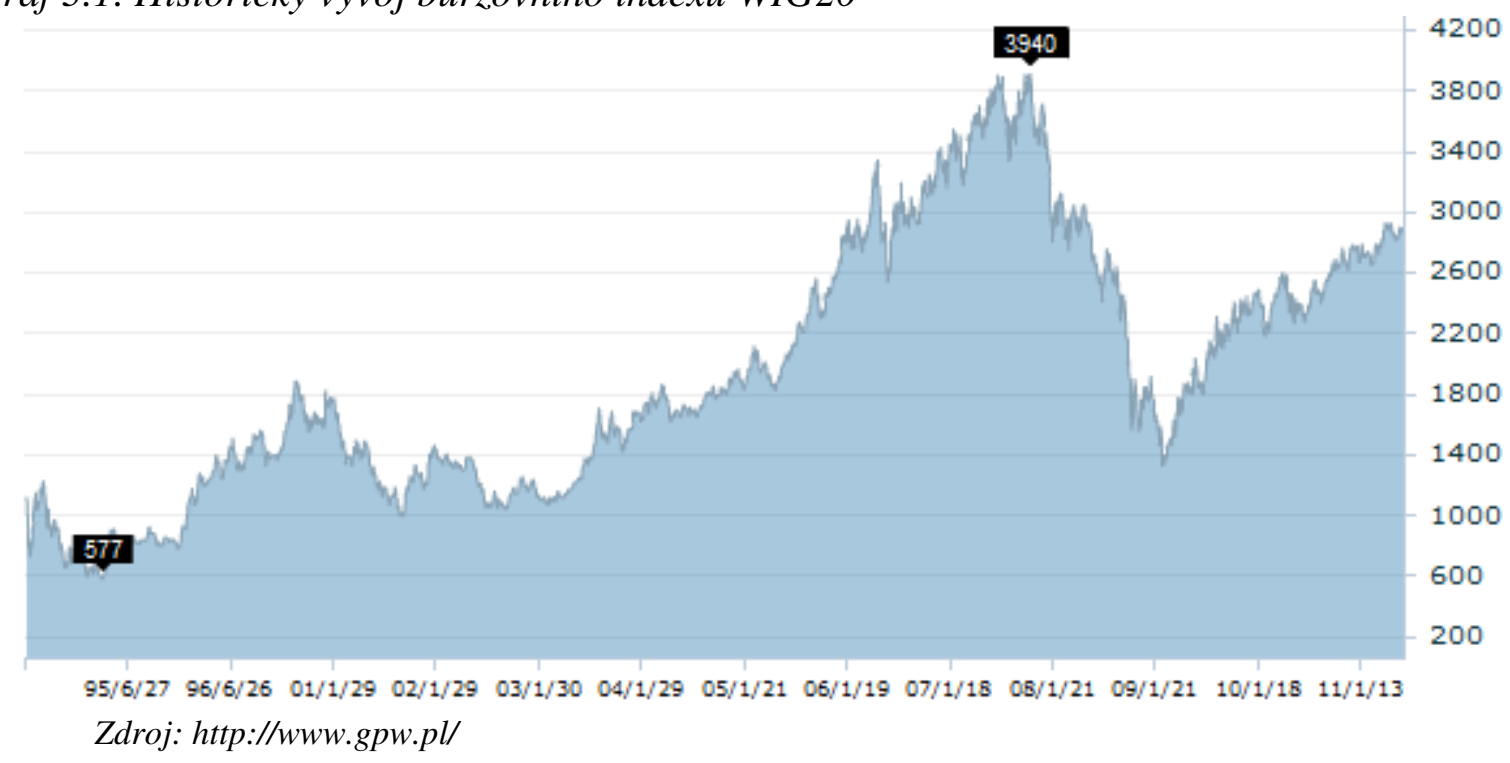

Graf 3.1 nám znázorn̆uje dlouhodobý vývoj hodnoty indexu WIG20 od počátku jeho obchodování, tj. 16. 4. 1994 do současnosti. Výchozí hodnota indexu WIG20 byla 1.000 bodů. Jakožto i jiné burzovní světové indexy, tak i index polské burzy vykazuje každoročně zajímavé zhodnocení pro své investory a z tohoto důvodu je polská burza především i pro zahraniční investory velice zajímavá. Z grafu můžeme vidět, že před vypuknutím hospodářské recese v roce 2008, se hodnota indexu blížila k 4.000 bodů. Aktuální hodnota indexu WIG20 se pohybuje okolo hodnoty 2.850 bodů. $^{3}$

\footnotetext{
${ }^{3}$ Hodnota indexu dne 10. 6. 2011 byla $2852,16$.
} 
Tabulka 3.1. Složení báze indexu WIG20 k 18. březnu 2011

\begin{tabular}{|c|c|c|c|c|}
\hline ISIN code & $\begin{array}{c}\text { Company } \\
\text { name }\end{array}$ & $\begin{array}{l}\text { Price } \\
\text { (PLN) }\end{array}$ & $\begin{array}{c}\text { Number of } \\
\text { shares }\end{array}$ & $\begin{array}{c}\text { Share } \\
(\%)\end{array}$ \\
\hline 1 PLPKO0000016 & PKOBP & 41,15 & 609490000 & 14,82 \\
\hline 2 PLKGHM000017 & KGHM & 168,2 & 136410000 & 13,56 \\
\hline 3 PLPEKAO00016 & PEKAO & 171 & 106931000 & 10,80 \\
\hline 4 PLPZU0000011 & $\mathrm{PZU}$ & 345 & 47332000 & 9,65 \\
\hline 5 PLPKN0000018 & PKNORLEN & 47,7 & 309999000 & 8,74 \\
\hline 6 PLPGER000010 & PGE & 22,89 & 574143000 & 7,76 \\
\hline 7 PLTLKPL00017 & TPSA & 16,8 & 603102000 & 5,99 \\
\hline 8 PLTAURN00011 & TAURONPE & 6,3 & 1017098000 & 3,79 \\
\hline 9 PLPGNIG00014 & PGNIG & 3,64 & 1623685000 & 3,49 \\
\hline 10 PLBZ00000044 & BZWBK & 218,7 & 21662000 & 2,80 \\
\hline 11 PLGSPR000014 & GETIN & 12,45 & 314248000 & 2,31 \\
\hline 12 PLBRE0000012 & BRE & 304 & 12734000 & 2,29 \\
\hline 13 PLSOFTB00016 & ASSECOPOL & 53 & 69483000 & 2,18 \\
\hline 14 LU0327357389 & KERNEL & 81 & 43500000 & 2,08 \\
\hline 15 PLLWBGD00016 & BOGDANKA & 113,5 & 30771000 & 2,06 \\
\hline 16 PLGTC0000037 & GTC & 20,97 & 159844000 & 1,98 \\
\hline 17 CZ0005112300 & CEZ & 133,6 & 19510000 & 1,54 \\
\hline 18 PLLOTOS00025 & LOTOS & 41,25 & 60797000 & 1,48 \\
\hline 19 PLTVN0000017 & TVN & 16,65 & 149912000 & 1,47 \\
\hline 20 PLPBG0000029 & PBG & 204 & 10055000 & 1,21 \\
\hline
\end{tabular}

Zdroj: http://static.gpw.pl/pub/files/PDF/komunikaty_indeksowe/2011_03_18_WIG20_ang.pdf

Změny v bázi indexu se provádějí ve čtvrtletním či ročním intervalu. Každoroční úprava vah jednotlivých akcií se provádí vždy třetí pátek v březnu. Hodnoty indexu jsou vypočítávány každých 15 sekund před započetím i během seance. Ranní hodnoty se začínají vypočítávat v 8:30 a závěrečná hodnota je spočítána v 16:40 minut místního času. Hodnoty indexu jsou zveřejňovány $\mathrm{v}$ polských celostátních denících a také na nejvýznamnějších mezinárodních internetových finančních portálech (Reuters, Bloomberg, atd.).

Ze složení báze indexu WIG20 můžeme vidět podstatný rozdíl ve složení báze oproti indexu pražské burzy PX. Báze indexu WIG20 je charakteristická tím, že ani jediná akcie společnosti nemá podíl větší než $20 \%$ na celkové bázi, zatímco v př́ípadě báze indexu PX jsou hned dvě společnosti, jejichž váha $\mathrm{v}$ indexu má větší než $20 \%$-ní podíl ${ }^{4}$. V obou případech ale tvoří podstatnou část báze indexu jen pár největších společností, které mají poté podstatný vliv na denní vývoj daných indexů.

\section{Analýza akciového trhu v Polsku}

V rámci analytické části bude pozornost zaměřena především na analýzu nejdůležitějších ukazatelů, které využívají k hodnocení trhů nejen analytici, ale taktéž široká veřejnost a odborníci z praxe. Použitými ukazateli budou vývoj indexu WIG20, počet obchodovaných společností a vývoj hodnoty tržní kapitalizace. Aby zjištěné výsledky měli lepší vypovídací schopnost, budou dosažené výsledky konfrontovány s aktuálními hodnotami výsledků na Burze cenných papírů Praha.

\footnotetext{
${ }^{4}$ http://www.pse.cz/Statistika/Burzovni-Indexy/default.aspx/default.aspx?bi=1
} 


\subsection{Výkonnost burzovního indexu WIG20}

Grafické znázornění historického vývoje indexu WIG20 již zachycuje graf v kapitole č. 3.1. Tato část je zaměřena na analýzu jeho vývoje ve srovnání s pražskou burzou a jejího indexu PX. Grafické znázornění vývoje obou indexů zachycuje graf 4. 1.

Graf 4. 1. Srovnání historického vývoje indexů WIG20 a PX

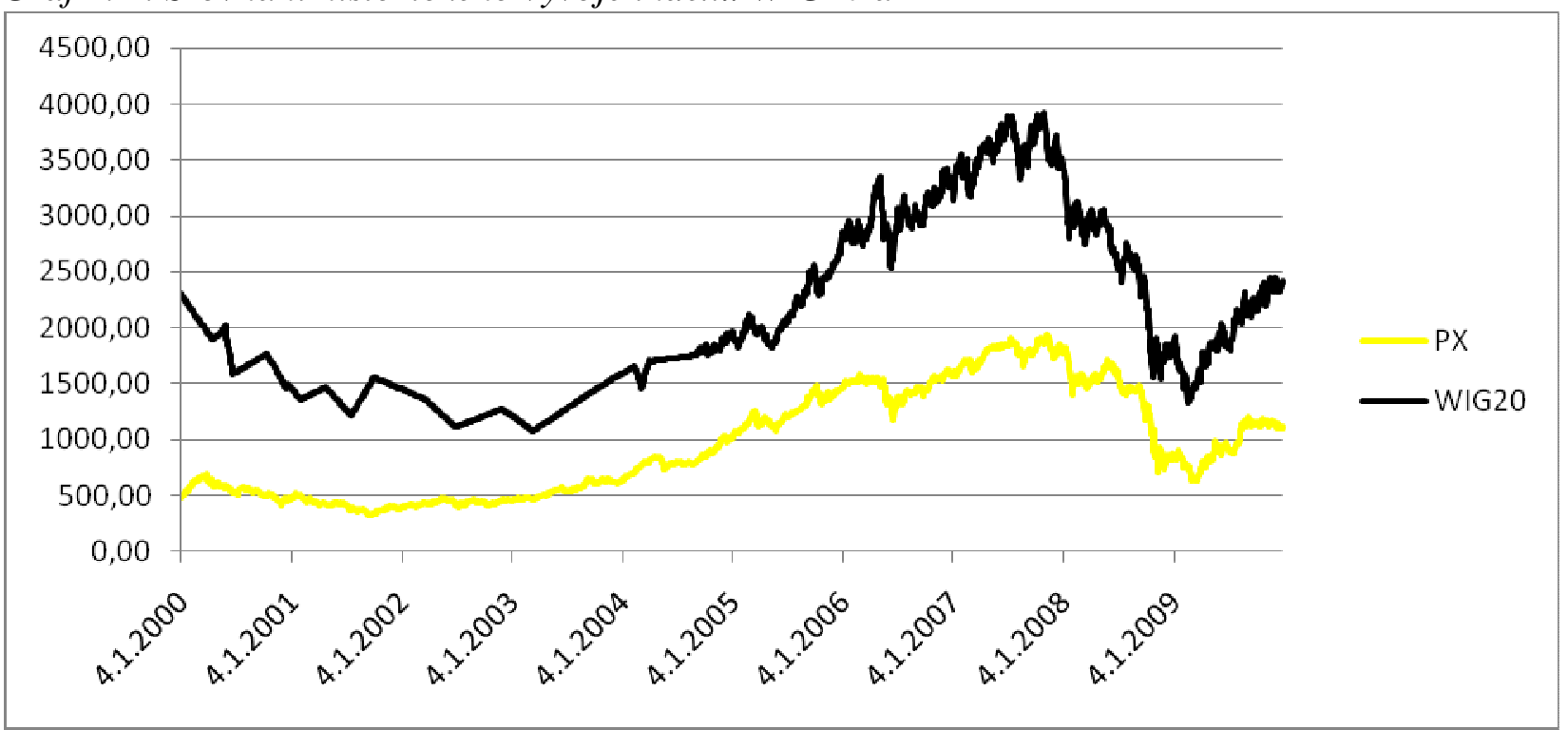

Zdroj: http://www.gpw.pl, http://www.pse.cz, vlastní zpracování

Z grafického vyjádření můžeme definovat jednu skutečnost, a to, že vývoj indexů WIG20 a PX má v dlouhodobé historii podobný vývojový charakter, tzn., že oba indexy společně reagují na veškeré negativní nebo pozitivní aspekty téměř podobně a následně mají podobný vliv na vývoj hodnoty jednotlivého indexu. Z grafu můžeme zároveň stanovit i tu skutečnost, že výkonnost polského indexu je ale na vyšší úrovni než indexu pražské burzy. S tím i úzce souvisí ta skutečnost, že vliv hospodářské recese na vývoj sledovaných indexů, byl silnější a rychlejší u indexu WIG20 než u indexu pražské burzy PX. Závěrem můžeme tedy konstatovat, že vývoj indexü WIG20 a PX má podobný charakter, ale jejich vývoj není na sobě nijak závislý. Tuto skutečnost nám potvrdila i provedená korelační analýza sledovaných indexů, kde korelační koeficient dosahuje neutrálních hodnot. ${ }^{5}$

\subsection{Počet obchodovaných společností}

Vývoj indexu každé burzy ovlivňuje mnoho faktorů, ale jedním z těch podstatných faktorů je počet obchodovaných společností na burze. Graf 4.2 znázorňuje počet obchodovaných společností na parketu Varšavské burzy a taktéž i na Burze cenných papírů v Praze.

\footnotetext{
${ }^{5}$ CHYLÍK, L. Vliv IPO na rozvoj akciových trhů v zemích Visegrádské čtyřky.
} 
Graf 4.2. Počet obchodovaných společností na parketu Varšavské a Pražské burzy

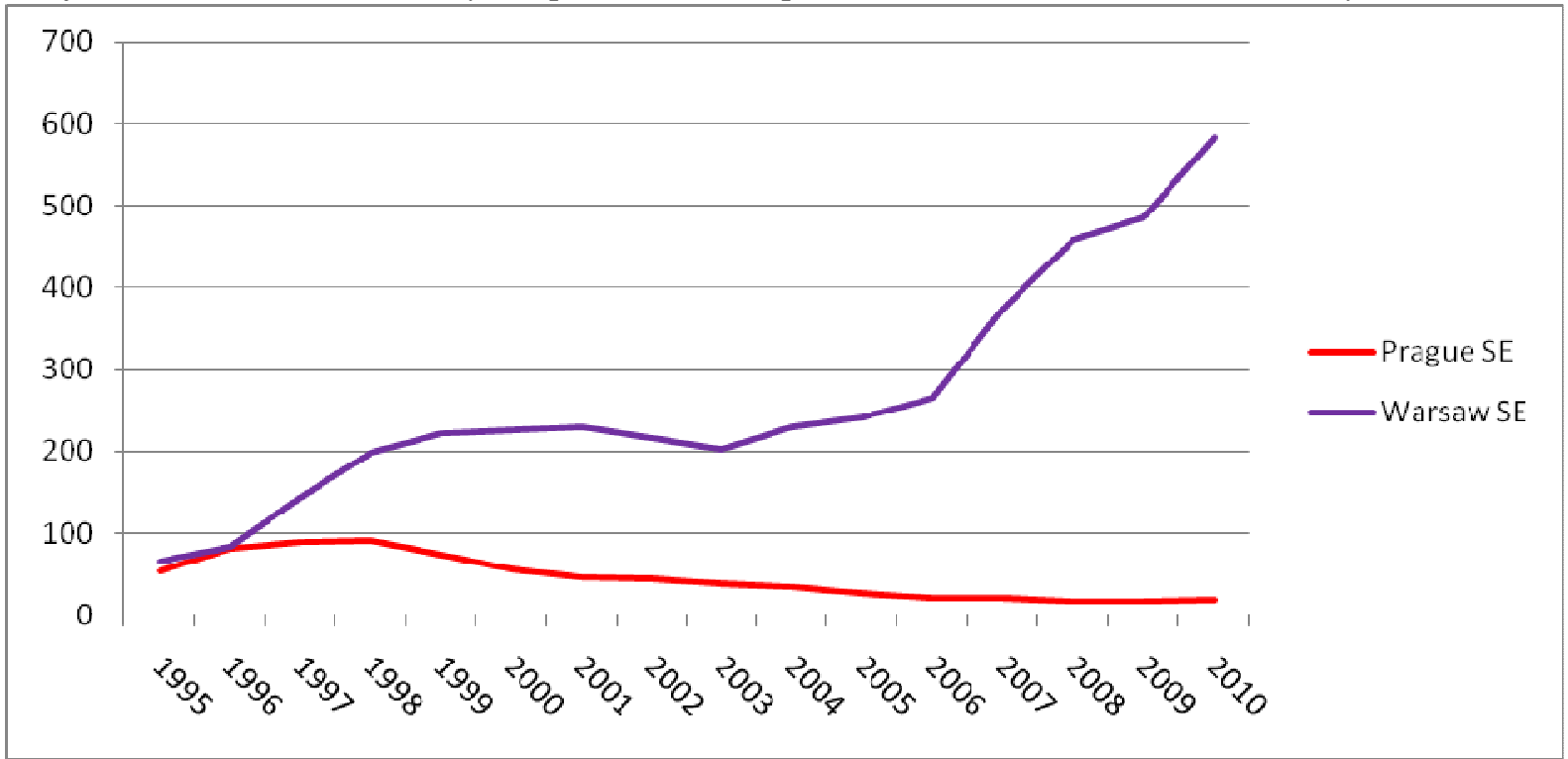

Zdroj: http://www.world-exchanges.org, vlastní zpracování

Z grafu 4. 2. můžeme vyčíst velice zajímavý trend, který je zcela odlišný v Praze a ve Varšavě. Zatímco na parketu pražské burzy, dochází neustále k postupnému snižování počtu obchodovaných společností, tak na parketu Varšavské burzy dochází naopak k neustálému zvyšování počtu obchodovaných společností. Můžeme zde vidět velice razantní nárůst v posledních letech, kde tento nárůst nezastavila ani probíhající hospodářská recese. Základním důvodem atraktivnosti polského akciového trhu je kromě jeho velikosti a zajímavosti pro zahraniční investory, taktéž ta skutečnost, že Varšavská burza otevřela již zmiňovaný trh NewConnect v roce 2007, který umožňuje vstoupit na kapitálové trhy i menším firmám s vysokým potencionálem růstu, ale za podstatně nižších nákladů. Tuto skutečnost můžeme považovat za jeden z těch hlavních faktorů, který ovlivňuji počet obchodovaných společností na sledovaných burzách.

Další velice zajímavou skutečností je ta, že kdybychom se podívali podrobněji na skladbu jednotlivých společností, se kterými se obchoduje na sledovaných burzách, tak zjistíme, že na parketu pražské burzy převažují zahraniční společnosti nad domácími, zatímco na parketu Varšavské burzy je to zcela naopak. Zde mají dominantní postavení tuzemské firmy, zahraniční společnosti jsou zde zastoupeny jen v malém měřítku (v roce 2010 se obchodovalo pouze s 15 zahraničními společnostmi).

\subsection{Tržní kapitalizace}

Počet obchodovaných společností má podstatný vliv na další sledovaný ukazatel, kterým je tržní kapitalizace sledovaných burz, tj. tržní kapitalizace Varšavské burzy a Burzy cenných papírů v Praze. Grafické vyjádření vývoje hodnoty tržních kapitalizací zachycuje graf 4.3. Pojem tržní kapitalizace nám vyjadřuje hodnotu firem podle tržního ohodnocení cen jejich akcií a v celkovém součtu poté velikost dané burzy ohodnocené samotnými investory. 


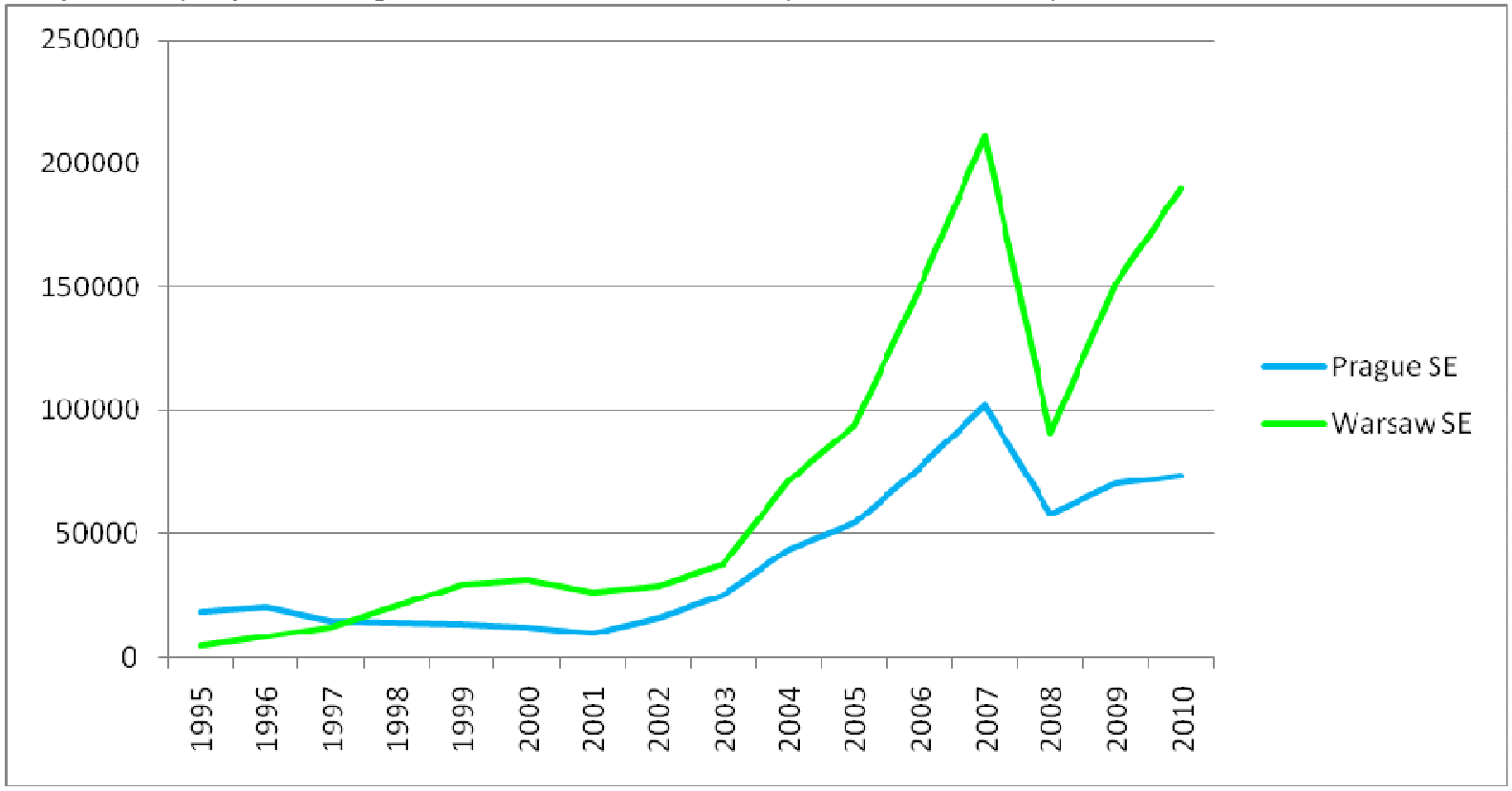

Zdroj: http://www.world-exchanges.org, vlastní zpracování

Na základě předchozích analytických částí bylo možné již předpovědět tu skutečnost, že tržní kapitalizace Varšavské burzy bude daleko větší než tržní kapitalizace burzy cenných papírů v Praze. Graf 4. 3. tuto skutečnost zcela potvrzuje. I přes podstatné sblížení hodnot tržní kapitalizace v roce 2008 (vzniklé následkem hospodářská recese a celosvětových dopadů na jednotlivé ekonomiky) se opětovně ukázala atraktivnost polské burzy, která se již téměř vrátila na původní úroveň $\mathrm{z}$ počátku krize $\mathrm{v}$ roce 2008. Pokud bychom chtěli dále předpokládat budoucí vývoj tohoto ukazatele, tak je zřejmé, že rozdíly mezi sledovanými burzami se budou neustále zvyšovat a zachovají si současný trend. V nejbližších letech nemůžeme ani očekávat, že by se hodnota těchto ukazatelů postupně sbližovala.

\subsection{Primární emise akcií (Initial Public Offering)}

IPO - primární veřejná nabídka akcií spojená se vstupem na burzovní trh. IPO jsou obvykle spojené se zavedením veřejné obchodovatelnosti akcií těchto společností (going public). ${ }^{6} \mathrm{Na}$ základě dostupných výsledků z předchozí podkapitoly (4.2) můžeme předpokládat, že pro nově emitující společnosti bude daleko zajímavější Varšavská burza, než burza v Praze. Tuto domněnku si potvrdíme na grafickém znázornění 4.4.

Graf 4.4 předkládá zcela jasné výsledky a potvrzuje vzniklou domněnku, že pro nově vstupující společnosti na kapitálové trhy je daleko zajímavějším trhem burza ve Varšavě než v Praze. Z grafu je patrný rapidní nárůst primárních emisí akcií v Polsku od roku 2002, zatímco trend na parketu pražské burzy spíše stagnuje, než aby vykazoval určitý vývoj. Tento trend je podpořen několika důležitými faktory. Jedním z nejdůležitějších faktorů je velikost polského trhu, jeho atraktivita a podmínky vstupu nových společností na trh (nové menší společnosti mají možnost získat finanční prostředky na trhu NewConnect). Dalším důležitým faktorem jsou institucionální investoři, respektive polské penzijní fondy, které mají možnost

\footnotetext{
${ }^{6}$ POLOUČEK, S. Peníze, banky a finanční trhy. s. 211
} 
uložit až $40 \%$ finančních prostředků do akcií, z toho pouze $5 \%$ mohou investovat do zahraničních investic ${ }^{7}$. Tato skutečnost pozitivně podporuje poptávku po nových cenných papírech a současně tudíž investice do tuzemských cenných papírů, konkrétně akcií tuzemských společností.

Graf 4.4. Vývoj počtu primárních emisí akcií Varšavské burzy a Pražské burzy

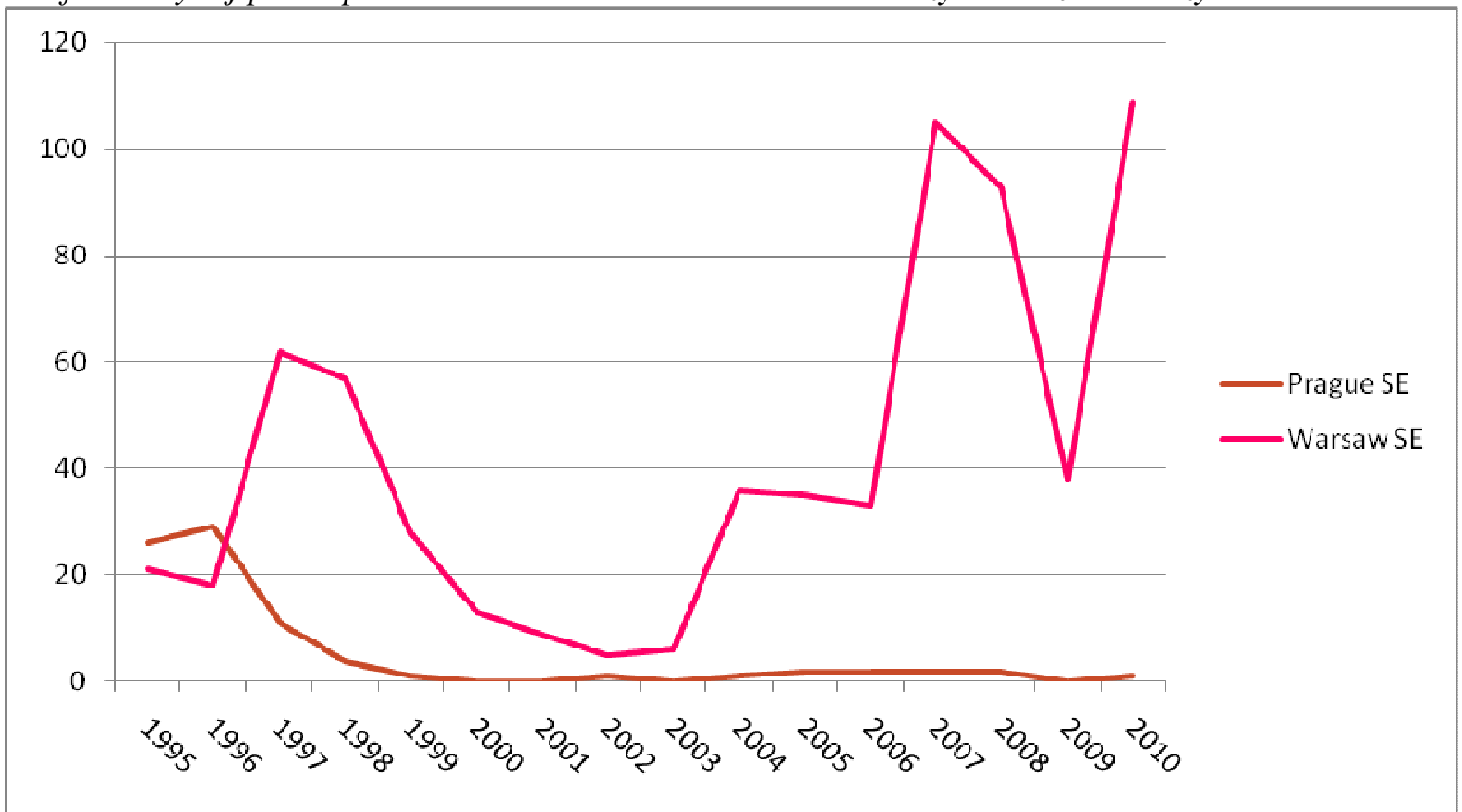

Zdroj: http://www.world-exchanges.org, vlastní zpracování

Pro příklad můžeme uvést několik posledních nejzajímavějších primárních emisí akcií na sledovaných burzách. Bezesporu nejzajímavější primární emisí akcií na Varšavské burze, a zároveň největší primární emisí akcií v její historii, byla emise akcií společnosti PGE (Polska Grupa Energetyczna ${ }^{8}$ ). Tato společnost vstoupila no polský kapitálový trh v roce 2009 a prozatím nepřinesla očekávané výsledky, které se do ní na počátku vkládaly.

Na parketu pražské burzy v roce 2009 nedošlo k realizaci nové emise „IPO“. Změna nastala na počátku roku 2010, kde na pražskou burzu vstoupila společnost KIT Digital, Inc., kterou ale můžeme řadit mezi ty menší primární emise na českém kapitálovém trhu. Tato emise byla ale přijata v rámci duálního listingu, tudíž tuto emisi nemůžeme zcela považovat za IPO ve smyslu prvního vstupu na veřejný organizovaný trh cenných papírů. Nově očekávanou primární emisí akcií na parketu pražské burzy je primární emise bankovní společnosti ČSOB. Předpokládaný termín vstupu na pražskou burzu byl červen 2010, ale prozatím tato emise do dnešního dne nebyla realizována.

Kdybychom se opět podívali blíže na skladbu nových primárních emisí akcií (viz. graf 4.5), tak si potvrdíme již zmíněnou skutečnost, že na parketu varšavské burzy převládají emise tuzemských společností, zatímco na parketu pražské burzy se za posledních 10 let neuskutečnila primární emise tuzemské společnosti.

\footnotetext{
${ }^{7}$ http://www.igte.com.pl/matiinf/2009/2009-001-eng.pdf

${ }^{8} \mathrm{http}: / /$ www.pgesa.pl
} 
Uvedený graf 4.5 jasně ukazuje na aktuální trendy na sledovaných burzách. Negativní výsledky pro pražskou burzu jsou způsobeny především menší atraktivností českého kapitálového trhu pro nově emitující společnosti, složitějšími podmínkami vstupu na kapitálový trh, neexistencí trhu po menší firmy jako např́klad trh NewConnect na Varšavské burze a taktéž velikostí ekonomiky. Polská ekonomika je co do velikosti několikrát větší než česká ekonomika, tudíž nemůžeme očekávat, že by český kapitálový trh byl velikostně podobný polskému kapitálovému trhu.

\section{Graf 4.5. Struktura primárních emisí akcií na WSE a BCPP}

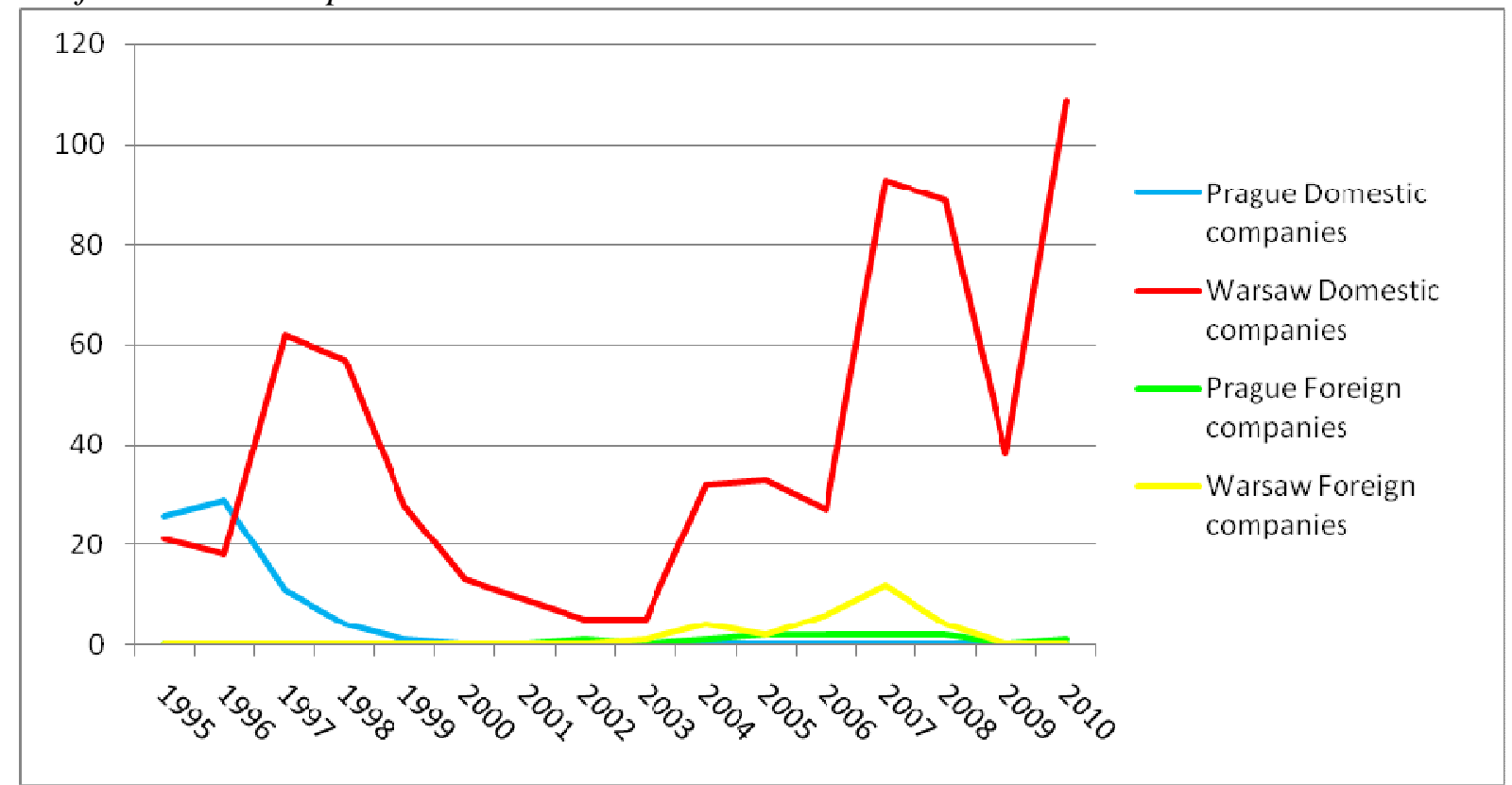

Zdroj: http://www.world-exchanges.org, vlastní zpracování

\section{Závěr}

Článek se zabývá základní charakteristikou polského kapitálového trhu a snaží se zaměřit na nejdůležitější aspekty současného vývoje akciového trhu. Nejpodstatnější roli na polském kapitálovém trhu hraje Varšavská burza cenných papírů, která v posledních letech zažívá nebývalý rozmach. Hlavním cílem bylo zanalyzovat kapitálový trh v Polsku se zaměřením na Varšavskou burzu a její hlavní index WIG20 a dále taktéž se blíže zaměřit na nejdůležitější ukazatele vývoje kapitálového trhu v Polsku. Pro srovnání výsledků a jejich lepší interpretaci jsem zvolil domácí BCPP a její hlavní index PX.

Ačkoliv můžeme vidět podobný historický vývoj obou sledovaných burz, tak aktuální světové postavení polského a českého akciového trhu je podstatně odlišné. Na základě veškerých zjištěných skutečností můžeme říci, že polský akciový trh je v současné době nejrozvinutějším akciovým trhem v zemích střední a východní Evropy. Svědčí o tom veškeré zjištěné ukazatele a potvrzuje to jejich dlouhodobý vývoj. Polský akciový trh začíná pomalu získávat velice důležité postavení mezi evropskými akciovými trhy a v delším časovém horizontu můžeme očekávat, pokračují růst jeho hodnoty včetně nově obchodovaných společností v rámci „,IPO“. 
Na druhou stranu český akciový trh se vyvíjí daleko pomaleji než v Polsku a prozatím se stabilizuje jeho postavení mezi akciovými trhy v zemích střední Evropy. Z okolních zemí se řadí mezi dynamicky se rozvíjející trhy. ${ }^{9}$ Důležitou událostí ve vývoji pražské burzy je odkup majoritního podílu rakouskou burzou ve Vídni, což můžeme řadit mezi ty pozitivnější stránky globalizace. Zde můžeme sledovat pomalé sjednocování pravidel burzovního obchodování a snahu o vytvoření nové burzovní aliance, jako je např́klad EURONEXT, OMX, apod. Rakouská burza ve Vídni již vlastní majoritní podíl na Budapešt'ské burze v Mad’arsku, dále v roce 2008 získala majoritní podíl na Lublaňské burze ve Slovinsku a taktéž majoritní podíl na Burze cenných papírů Praha. Současně burza cenných papírů ve Vídni úzce spolupracuje i $\mathrm{s}$ dalšími burzami v regionu, především pak s burzami v Bukurešti, Sarajevu a Banja Luce.

Mezi nejdůležitější aspekty ovlivňující vývoj polského a českého akciového trhu řadíme tyto:

$>$ atraktivnost regionu střední Evropy pro zahraniční investory

$>$ velikost ekonomiky

$>$ historický vývoj jednotlivých burz

$>$ podmínky vstupu pro nové společnosti na akciové trhy

$>$ struktura obchodních trhů jednotlivých burz

$>$ možnosti investic institucionálních investorů do akciových titulů

Uvedené aspekty nejvíce ovlivnily vývoj polského akciového trhu, který na aktuální požadavky trhů a aktuální trendy zareagoval tím nejlepším způsobem. Již při obnovení Varšavské burzy cenných papírů v roce 1991 šla polská vláda jinou cestou než česká vláda, a požádala o pomoc při tvorbě Varšavské burzy Svaz francouzských burz (Sociéte de Bourses Francaises). Zde již můžeme vidět první náznaky budoucího odlišného postavení mezi světovými akciovými trhy.

Dalším velice důležitým faktorem je velikost polské ekonomiky, která je větší než česká ekonomika. $Z$ tohoto důvodu lze předpokládat větší počet potencionálních firem, pro které by mohl být vstup na akciové trhy zajímavý a taktéž současně větší počet potencionálních investorů s volnými finančními prostředky.

Růstu akciového trhu v Polsku taktéž přispívá aktuální investični struktura polského důchodového systému, který byl v roce 2004 reformován až k dnešní podobě, kdy polské penzijní fondy mohou do akciových titulů investovat až $40 \%$ finančních prostředků. Pokud se podíváme na české penzijní fondy tak dojdeme k závěru, že portfolia českých penzijních fondů obsahují pouze okolo $1 \%$ akciových titulů. Tak nízkou úroveň akcií v portfoliu nemají žádné okolní penzijní fondy ${ }^{10}$.

Posledním důležitým bodem je vznik nového trhu NewConnect při Varšavské burze, který od svého založení nastartoval raketový nástup v počtu nově obchodovaných společností. Tuto skutečnost nám znázorňuje uvedený graf.

\footnotetext{
${ }^{9}$ CHYLÍK, L. Vliv IPO na rozvoj akciových trhů v zemích Visegrádské čtyřky.

${ }^{10} \mathrm{http} / / /$ idea.cerge-ei.cz/documents/vyzkum_201101.pdf
} 
Graf: Celkový počet společností a počet nových společností uvedených na trhu NewConnect

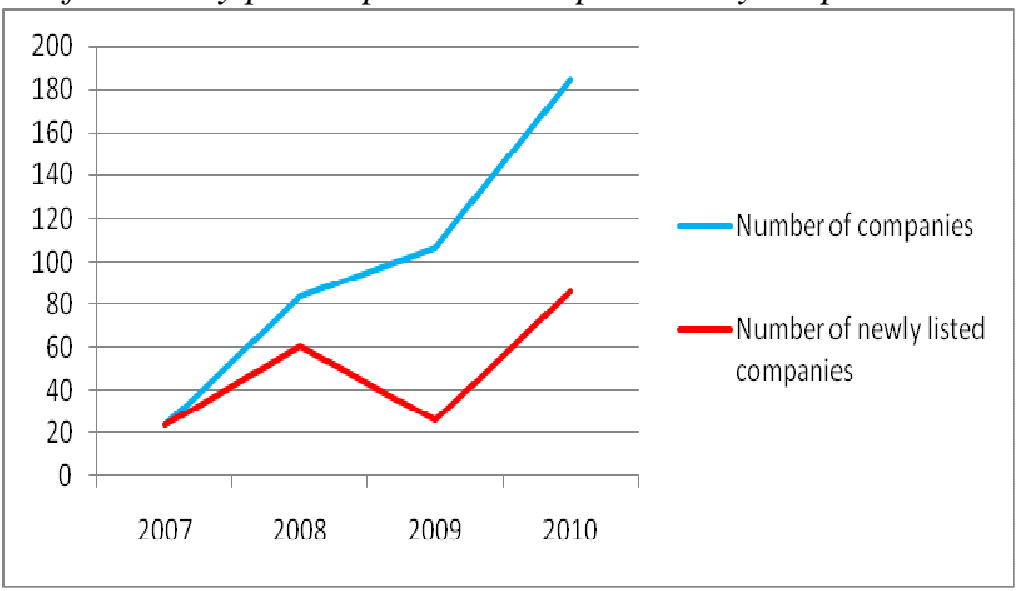

Zdroj: http://www.world-exchanges.org, vlastní zpracování

Hlavní podstatou tohoto trhu je jeho jednoduchost a vstřícnost podmínek vstupu nových společností na akciový trh $\mathrm{v}$ Polsku. Přímým zaměřením jsou nově vznikající firmy s vysokým potencionálem růstu do budoucna a jejich možnost získat dostatečné finanční prostředky na jejich budoucí růst a rozvoj. Údaje o vývoji tržní kapitalizace tohoto trhu hovoří zcela jasně o atraktivnosti těchto firem a růstu objemu investic.

Graf: Vývoj tržní kapitalizace trhu NewConnect v letech 2007 - 2010

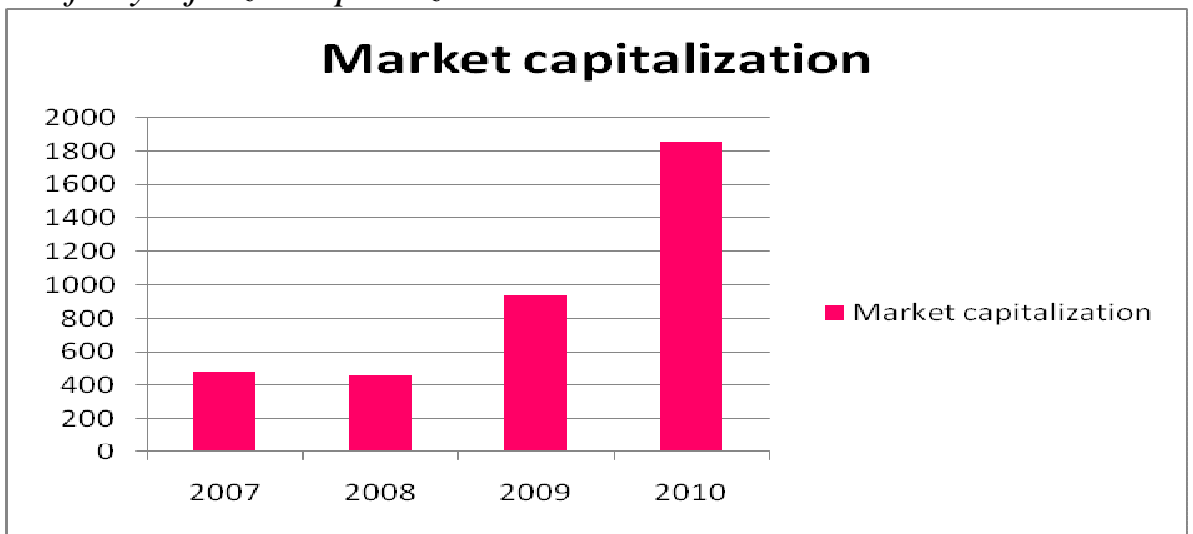

Zdroj: http://www.world-exchanges.org, vlastní zpracování

Z výše uvedených výsledků můžeme tedy stanovit, že polský akciový trh je v současné době na lepší vývojové pozici než český akciový trh. Faktorů je hned několik - velikost trhu, atraktivnost, podmínky vstupu nových společností na trhu, struktura trhu a v neposlední řadě možnosti investování institucionálních investorů. V budoucím vývoji bude určitě velice zajímavé analyzovat následný trend polského akciového trhu a současně taktéž změnu podmínek v případě českého akciového trhu. Námětem pro budoucí vědecký výzkum se jeví taktéž analýza sledovaných ukazatelů polského akciového trhu a nově vznikajícího uskupení v čele s rakouskou burzou ve Vídni. 


\section{Literatura:}

[1] HLAVÁČ, J., SCHNEIDER, O. Finanční výkonnost penzijních fondů ve střední Evropě: Proč jsou české fondy nejhorší? Praha: Národohospodářský ústav AVČR, 2011. Odkaz: http://idea.cerge-ei.cz/documents/vyzkum_201101.pdf

[2] CHYLÍK, L. Vliv IPO na rozvoj akciových trhů v zemích Visegrádské čtyřky. Vědecký časopis Ekonomika a management, č. 4/2010. Praha: Vysoká škola ekonomická Praha, 2010. ISSN 1802-8470.

[3] JÍLEK, J. Akciové trhy a investování. Praha: Grada Publishing, 2009. ISBN 978-80247-2963-3.

[4] MELUZÍN, T., ZINECKER, M. IPO Prvotní veřejná nabídka akcií jako zdroj financování rozvoje podniku. Praha: CPress, 2009. ISBN 978-80-251-2620-2.

[5] MUSÍLEK, P. Finanční trhy: instrumenty, instituce a management 1. část. 1. vyd. Praha: VŠE, 1996, 417 s. ISBN 80-7079-726-6.

[6] MUSÍLEK, P. Trhy cenných papírů. 1. vyd. Praha: Ekopress, 2002, 459 s. ISBN 80-86119-55-6.

[7] NÝVLTOVÁ, R., REŽŇÁKOVÁ, M. Mezinárodní kapitálové trhy. Praha: Grada Publishing, 2007. ISBN 978-80-247-1922-1.

[8] PAVLÁT, V. Kapitálové trhy a burzy ve světě. Praha, Grada Publishing, 1992. ISBN 80-85424-90-8.

[9] The opinion of Polish Chamber of Pension Funds about the proposed amendments of 31 January 2009 to Law on organisation and operation of pension funds: http://www.igte.com.pl/matiinf/2009/2009-001-eng.pdf

[10] http://www.world-exchanges.org http://www.pse.cz http://www.gpw.pl http://www.newconnect.pl

\section{JEL klasifikace: G15}

\section{Ing. Lukáš Chylík}

Interní doktorand Katedra financí

Obchodně podnikatelská fakulta v Karviné

Slezská univerzita v Opavě

Univerzitní náměstí 1934/3, 73340 Karviná

chylik@opf.slu.cz 